\title{
THE IN-VITRO CAFFEINE CONTRACTURE TEST: INFLUENCE OF THE MUSCLE HISTOCHEMICAL PROFILE ON TEST RESULTS
}

\author{
A.K.W. Brownell AND M. SZABO
}

\begin{abstract}
In vitro caffeine contracture tests were carried out on whole rat muscle composed primarily of either histochemical type I or type II fibers. Muscles composed primarily of type I fibers developed contractures at lower concentrations of caffeine and had lower caffeine specific concentrations than muscles composed primarily of type II fibers. These findings indicate that the histochemical profile of a muscle can influence the results of the in-vitro caffeine contracture test.
\end{abstract}

\section{Key Words: Malignant Hyperthermia, In-Vitro Caffeine Contracture Test, Muscle Histochemistry.}

\section{INTRODUCTION}

MaLignant Hyperthermia (MH), a pharmacogenetic disease of skeletal muscle, is triggered by potent inhalation anaesthetics and depolarizing muscle relaxants ${ }^{1}$ and is associated with a high mortality rate ${ }^{2}$.

Several tests are used to screen individuals for MH susceptibility ${ }^{3-9}$ Pharmacological testing of muscle biopsy specimens has now been firmly established as the most useful screening procedure. ${ }^{10}$ It has been shown by Britt, et al. that temperature can influence the results of the in-vitro caffeine contracture test while the physical characteristics of the specimen such as weight, length or diameter has little or no effect on the amplitude of the caffeine induced contracture. ${ }^{11}$

The purpose of this study was to investigate whether the histochemical profile of a muscle could influence the results of the caffeine contracture study. To do this, we evaluated the caffeine contracture response in rat muscles where one can repeatedly obtain individual muscles of predominantly either histochemical type I or type II fiber composition.

An abstract of this work has been published. ${ }^{12}$

A.K.W. Brownell, M.D., F.R.C.P.(C), Associate Professor, Department of Clinical Neurosciences and Medicine; M. Szabo, B.Sc., Medical Student: The University of Calgary, Health Sciences Centre, 3330 Hospital Drive N.W., Calgary, Alberta, Canada T2N $4 \mathrm{NI}$.

This research was supported by a grant from the Medical Services Research Foundation of Alberta.

\section{Methods}

Male white rats (University of Calgary strain) weighing approximately 200 to 300 grams were sacrificed by decapitation. Soleus, composed primarily of type I fibers ${ }^{13}$ and extensor digitorum longus muscles (EDL), composed primarily of type II fibers, ${ }^{13}$ were dissected out at room temperature and placed in oxygenated KrebsRinger solution. One end of each muscle was attached to a special muscle holder and the muscle and holder were immersed in a muscle bath containing oxygenated Krebs-Ringer at $37^{\circ} \mathrm{C}$. The free end of the muscle was attached to a transducer with silk thread and the transducer was attached to a polygraph. Baseline tension was set at 1 gram.

The muscles were allowed to equilibrate for 30 minutes and then one of each muscle pair was exposed to halothane one per cent for 20 minutes. Contractures were recorded in each muscle four minutes following the addition of $1,2,4,8$, 16 and $32 \mathrm{mM}$ caffeine solutions. Caffeine dose response curves were plotted for all muscles and their caffeine specific concentrations were calculated. The caffeine specific concentration is defined as the concentration of caffeine at which a 1 gram contracture is produced. ${ }^{4}$

\section{Results}

The results of the in-vitro caffeine contracture test for all muscles are shown in tables I and II. The caffeine dose response curves (Figure 1) for the soleus are shifted to the left when compared 


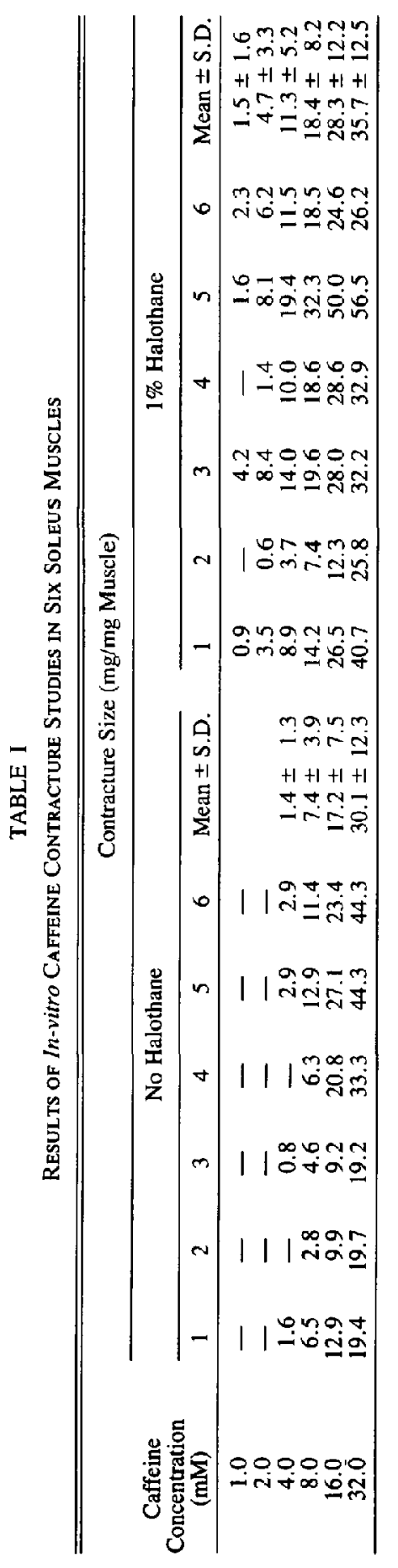


TABLE II

Results of In-vitro Caffeine Contracture Studies in Five EDL Muscles

\begin{tabular}{|c|c|c|c|c|c|c|c|c|c|c|c|c|}
\hline \multirow{3}{*}{$\begin{array}{c}\text { Caffeine } \\
\text { Concentration } \\
(\mathrm{mM})\end{array}$} & \multicolumn{12}{|c|}{ Contracturc Sizc (mg/mg Muscle) } \\
\hline & \multicolumn{6}{|c|}{ No Halothane } & \multicolumn{6}{|c|}{$1 \%$ Halothane } \\
\hline & 1 & 2 & 3 & 4 & 5 & Mean \pm S.D. & 1 & 2 & 3 & 4 & 5 & Mean \pm S.D. \\
\hline 1.0 & - & - & - & - & - & - & - & - & - & - & - & - \\
\hline 2.0 & - & - & - & - & - & - & - & - & - & - & - & - \\
\hline 4.0 & - & - & - & - & - & - & - & - & - & - & - & - \\
\hline 8.0 & - & - & 0.6 & 0.3 & 1.0 & $0.4 \pm 0.4$ & 1.1 & 0.8 & 0.6 & 0.4 & 1.8 & $0.9 \pm 0.6$ \\
\hline 16.0 & 2.4 & 0.7 & 1.3 & 0.7 & 1.7 & $1.4 \pm 0.7$ & 7.1 & 4.6 & 6.7 & 1.9 & 6.3 & $5.3 \pm 2.1$ \\
\hline 32.0 & 8.9 & 1.5 & 3.9 & 3.3 & 4.1 & $4.3 \pm 2.7$ & 21.9 & 7.6 & 10.3 & 13.9 & 8.2 & $12.4 \pm 5.9$ \\
\hline
\end{tabular}

TABLE III

Caffeine Concentration Required to Increase Baseline Tension by One Gram (Caffeine Specific Concentration)

\begin{tabular}{lccccc}
\hline \hline & \multicolumn{4}{c}{ Caffeine Specific Concentrations (mM) } \\
\cline { 2 - 3 } $\begin{array}{c}\text { Rat } \\
\text { Number }\end{array}$ & No Halothane & 1\% Halothane & & \multicolumn{2}{c}{ EDL } \\
\cline { 2 - 3 } \cline { 5 - 7 } & 9.6 & 4.0 & & 19.0 & 11.0 \\
2 & 12.0 & 6.4 & & 54.0 & 14.0 \\
3 & 12.5 & 1.7 & & 27.0 & 10.5 \\
4 & 9.8 & 3.2 & & 32.0 & 18.0 \\
5 & 5.2 & 2.0 & & 25.0 & 12.0 \\
6 & 5.6 & 2.4 & & - & \\
Mean \pm S.D. & $9.1 \pm 3.1$ & $3.3 \pm 1.7$ & & $31.4 \pm 13.5$ & $13.0 \pm 3.2$ \\
\hline
\end{tabular}

to those of EDL. Caffeine induced contractures for both the soleus and EDL were potentiated by halothane.

The caffeine specific concentrations for soleus, without halothane, ranged from 5.2 to $12.5 \mathrm{mM}$ caffeine (mean $9.1 \mathrm{mM}$ ) and from 1.7 to $6.4 \mathrm{mM}$ caffeine (mean $3.3 \mathrm{mM}$ ) with one per

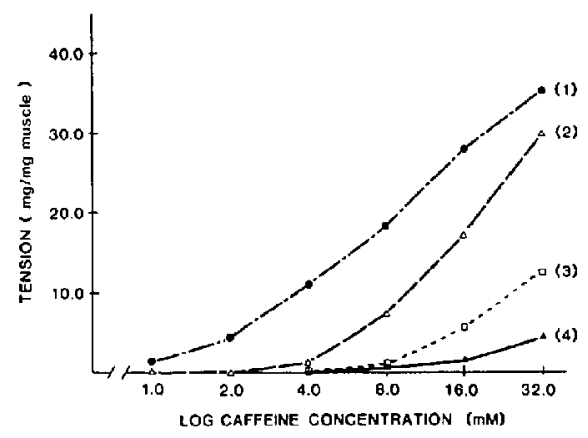

Figure 1. Caffeine dose response curves for soleus and EDL muscles (mean values). [(1) Soleus with $1 \%$ halothane, (2) Soleus, (3) EDL with $1 \%$ halothane, (4) EDL] cent halothane. Similar values for EDL were 19.0 to $54.0 \mathrm{mM}$ caffeine (mean $31.4 \mathrm{mM}$ ) and 10.5 to $18.0 \mathrm{mM}$ caffeine (mean $13.0 \mathrm{mM}$ ). These results are shown in Table III.

\section{Discussion}

Our experiment demonstrates that the caffeine contracture study is influenced by the histochemical profile of the muscle. Muscle composed of predominantly type I fibers developed contractures at lower caffeine concentrations and had lower caffeine specific contractions than muscle composed primarily of type II fibers. Halothane potentiated both of these measurements.

In view of the demonstrated relationship, albeit in an animal model, it will be necessary to carry out similar studies on human biopsy material to determine whether fiber type composition of human muscle could influence the results of the caffeine contracture test. Until the results of such studies are available, the caffeine contracture response in human muscle of predominantly one fiber type composition should be 
interpreted cautiously when carrying out diagnostic testing to assess $\mathrm{MH}$ susceptibility.

\section{REFERENCES}

1. Gronert, G.A. Malignant Hyperthermia. Anesthesiology 53: 395-425 (1980)

2. Wilson, R.D., Dent T.E., Traber, D.L., MCCOY, N.R. \& ALLEN, C.R. Malignant Hyperpyrexia With Anesthesia. JAMA 202: 183-186 (1967).

3. Kalow, W., Britt, B.A., Terreau, M.E. \& HAIST, C. Metabolic Error of Muscle Metabolism After Recovery From MH. Lancet II: 895-898 (1970).

4. Kalow, W., Britt, B.A. \& Richter, A. The Caffeine Test of Isolated Human Muscle in Relation to Malignant Hyperthermia. Can. Anaesth. Soc. J. 24: 678-694 (1977).

5. Aldrete, J.A., Padfield, A., Solomon, C.C. \& Ruhright, M.W. Possible Predictive Tests for Malignant Hyperthermia During Anesthesia. JAMA 215: 1465-1469 (1971).

6. Britt, B.A., Endrenyi, L., Peters, P.L., KwONG, F.H.F. \& KADIJEVIC, L. Screening of Malignant Hyperthermia Susceptible Families by Creatine Phosphokinase Measurement and Other Clinical Investigation. Can. Anaesth. Soc. J. 23: 263-284 (1976)
7. Britt, B.A., Enrenyi, L., Kalow, W. \& PETERS, P.L. The Adenosine Triphosphate (ATP) Depletion Test: Comparison With the Caffeine Contracture Test as a Method of Diagnosing Malignant Hyperthermia Susceptibility. Can. Anaesth. Soc. J. 23 (6): 624-635 (1976).

8. Willner, J., WOOd, D.S., Cerri, C. \& BritT B. Increased Myophosphorylase A in Malignant Hyperthermia. N. Eng. J. Med. 303 (3) $138-140(1980)$

9. Solomons, C.C., McDermott, N. \& MahowALD, M. Screening for Malignant Hyperthermia With a Platelet Bioassay. N. Eng. J. Med. 303 (11): 642 (1980)

10. KALOW, W. Second International Symposium on Malignant Hyperthermia. New York: Grune \& Stratton (1978)

11. Britt, B.A., Endrenyi, L., Scott, E., et al. Effects of Temperature Time and Fascicle Size on the Caffeine Contracture Test. Can. Anaesth. Soc. J. 27: 1-11 (1980).

12. Brownell, A.K.W. \& Szabo, M. The Influence of the Histochemical Profile of Muscle on the In-Vitro Caffeine Contracture Test. The Can. J. of Neuro. Sci. 7 (4): 327 (1980)

13. Ariano, M.A., Armstrong, R.B. \& EdgerTON, V.R. Hindlimb Muscle Fibre Populations of Five Mammals. J. of Histochem and Cytochem. $21(1): 51-55(1973$

\section{RÉsumÉ}

Le but de ce travail était d'évaluer l'influence du caractère histochimique des muscles utilisés dans les tests de contractures à la caféine in vitro, selon que des fibres musculaires de type I ou de type II sont utilisées. A cette fin nous avons effectué des montages à partir de muscles entiers de l'un et de l'autre type, prélevés chez le rat. Les contractures survenaient à des concentrations de caféine moindres dans le cas des fibres de type I et les concentrations spécifiques de caféine (mM de caféine requises pour élever d'un gramme la tension du muscle) étaient également inférieures dans le cas de fibres de type I que dans celui des fibres de type II. Ces résultats indiquent que le profil histochimique du muscle utilisé peut modifier les résultats des tests de contractures à la caféine effectués in vitro. 